\title{
Cardiac structural and functional findings in Persian cats with autosomal dominant polycystic kidney disease
}

\author{
Juliana Mariotti Guerra ${ }^{1,2}$ A Arine Pellegrino $^{3}$ Alexandre Gonçalves Teixeira Daniel $^{4}(\mathbb{D}$ \\ Mariana Ferreira de Freitas $^{3}$ Natália Cavalca Cardoso $^{1}$ (D) Rebecca Bastos Pessoa ${ }^{3}$ (D) \\ Gabriel Garone de Lucca ${ }^{3}$ Maria Helena Matiko Akao Larsson ${ }^{3}$ iD Luiz Fernando Onuchic ${ }^{5}$ iD \\ Felisbina Luisa Queiroga ${ }^{6}$ (D) Bruno Cogliati ${ }^{*}$ (D)
}

\author{
${ }^{1}$ Departamento de Patologia, Faculdade de Medicina Veterinária e Zootecnia, Universidade de São Paulo, 05508-270, SP, Brasil. E-mail: \\ bcogliati@usp.br. "Corresponding author. \\ ${ }^{2}$ Núcleo de Patologia Quantitativa, Centro de Patologia, Instituto Adolfo Lutz, SP, Brasil. \\ ${ }^{3}$ Departamento de Clínica Médica, Faculdade de Medicina Veterinária e Zootecnia, Universidade de São Paulo, SP, Brasil. \\ ${ }^{4}$ Gattos - Clínica Especializada em Medicina Felina, SP, Brasil. \\ ${ }_{5}^{5}$ Departamento de Clínica Médica, Faculdade de Medicina, Universidade de São Paulo, SP, Brasil. \\ ${ }^{6} \mathrm{CITAB}$, Centro de Investigação em Tecnologias Agroambientais e Biológicas, Universidade de Trás-os-Montes e Alto Douro, Vila Real, Portugal.
}

ABSTRACT: Autosomal dominant polycystic kidney disease (ADPKD) has been related to left ventricular structural and functional abnormalities in human patients. The present study aimed to evaluate the cardiac structural and functional findings in Persian cats with ADPKD. Client-owned ADPKD $(n=12)$ and non-ADPKD $(n=12)$ Persian cats were enrolled in this study. The animals underwent echo- and electrocardiographic (ECG) examinations, and non-invasive measurements of systolic blood pressure (SBP) were obtained. Both groups were similar regarding hematological and biochemical parameters, including white blood cell count and levels of blood urea nitrogen, creatinine, total protein and thyroxine. There were no differences related to ECG parameters between ADPKD and non-ADPKD cats. Left ventricular hypertrophy (LVH) was demonstrated in 6/12 (50\%) normotensive ADPKD cats with preserved renal function. There were no differences between animal groups regarding the echocardiographic parameters, including left ventricular ejection fraction and shortening fraction; however, basal interventricular septal thickness at end-diastole near the left ventricular outflow tract and aortic artery flow velocity showed slightly elevated values in ADPKD-cats. Our study revealed that Persian cats with ADPKD do not reproduce the functional and structural cardiac phenotype reported in human patients; however, large-scale cohort studies are necessary to distinguish the possibilities of a true linkage between ventricular myocardial hypertrophy and ADPKD in this breed.

Key words: feline, genetic disease, renal disease, heart, echocardiography.

\section{Achados estruturais e funcionais cardíacos em gatos persas com doença renal} policística autossômica dominante

RESUMO: A doença renal policística autossômica dominante (DRPAD) tem sido relacionada a anormalidades estruturais e funcionais de ventrículo esquerdo em pacientes humanos. O objetivo do presente estudo foi avaliar os achados estruturais e funcionais cardiacos em gatos persas com DRPAD. Gatos persas pertencentes à clientes com DRPAD $(n=12)$ e sem DRPAD $(n=12)$ foram envolvidos neste trabalho. Os animais foram submetidos aos exames de eco e eletrocardiografia (ECG) e foram obtidas medições não-invasivas da pressão arterial sistólica (PAS). Ambos os grupos apresentaram valores semelhantes em relação aos parâmetros hematológicos e bioquímicos, incluindo contagem de glóbulos brancos e níveis séricos de ureia, creatinina, proteína total e tiroxina. Não houve diferença em relação aos parâmetros do ECG entre os gatos com ou sem DRPAD. A hipertrofia ventricular esquerda foi demonstrada em 6/12 (50\%) dos gatos normotensos com DRPAD e função renal preservada. Não houve diferenças entre os grupos em relação aos parâmetros ecocardiográficos, incluindo fração de ejeção e fração de encurtamento do ventrículo esquerdo, entretanto a espessura septal interventricular basal na diástole na via de saída do ventrículo esquerdo e a velocidade do fluxo da artéria aórtica mostraram valores ligeiramente elevados em gatos com DRPAD. Nosso estudo revelou que gatos persas com DRPAD não reproduzem o fenótipo cardiaco funcional e estrutural encontrado em pacientes humanos. No entanto, estudos de coorte em larga escala são necessários para distinguir as possibilidades de uma verdadeira ligação entre a hipertrofia ventricular do miocárdio e a DRPAD nesta raça.

Palavras-chave: felino, doença genética, doença renal, coração, ecocardiografia.

\section{INTRODUCTION}

Autosomal dominant polycystic kidney disease (ADPKD) is phenotypically characterized by the presence of multiple cysts in the renal parenchyma and, occasionally, in liver and pancreas, being an important cause of end-stage renal disease (BASTOS \& ONUCHIC, 2011). In humans, 78\% 
of the cases are caused by mutations in the PKD1 gene (type 1 ADPKD), while in $15 \%$ of the patients the disease occurs due to mutations in PKD2 (type 2 ADPKD) (CORNEC-LE GALL et al., 2018). Approximately $7 \%$ of the affected families; however, are currently genetically unresolved. The $P K D 1$ and $P K D 2$ genes, in turn, encode the integral membrane glycoproteins polycystin-1 and polycystin-2, respectively. Disruption of polycystins affects proliferation, apoptosis and planar cell polarity, and promotes transepithelial chloride and fluid secretion (DELMAS, 2004).

Cardiovascular manifestations and complications, including systemic arterial hypertension, increased left ventricular mass and idiopathic dilated cardiomyopathy, are a major cause of morbidity and mortality in humans with ADPKD. Echocardiography in normotensive ADPKD individuals shows increased left and right ventricular mass and volume with normal ejection fractions and decreased end-diastolic relaxation compared to unaffected age and sex-matched controls, suggesting that deficiency of polycystin- 1 or polycystin- 2 is an independent factor for the development of the cardiac phenotype in affected individuals (CHAPMAN et al., 1997; ECDER et al., 1999). Other potential cardiovascular alterations in ADPKD human patients include biventricular diastolic and endothelial dysfunction, increased thickness of the intima-media, impaired coronary flow velocity reserve, aneurysms and valvular defects (ECDER, 2013).

In recent years, seminal studies addressed more deeply the mechanisms underlying the cardiac phenotype associated with ADPKD. BALBO et al. (2016) showed that different $P k d l$-deficient mouse models, including noncystic normotensive $P k d 1^{+/}$and cystic hypertensive $P k d l^{\text {flox/flox}}:$ Nestin ${ }^{\text {cre }}$ animals, developed systolic dysfunction and reduced myocardial deformation. $P k d l^{\text {flox/flox}}:$ Nestin ${ }^{\text {cre }}$ mice also presented diastolic dysfunction. These findings strongly supported a primary role for PKD1 deficiency in ADPKD-associated heart dysfunction, while suggested that hypertension may worsen this phenotype with age. In line with these findings, PEDROZO et al. (2015) have shown that polycystin-1 is required for the normal baseline function of cardiomyocytes. This study revealed, on the other hand, that this protein is also necessary for cardiomyocyte stretch-induced hypertrophy. Polycystin-2 has also been shown to play a significant role in cardiac function (PAAVOLA et al., 2013). This report not only revealed that ADPKD patients have an increased risk of developing idiopathic dilated cardiomyopathy, particularly type 2 ADPKD cases, but also showed that zebrafish lacking this protein develop manifestations consistent with heart failure.

The ADPKD is also a genetic disorder that affects $13-46 \%$ of Persian cats and Persianrelated breeds populations worldwide (LEE et al., 2010). Ultrasound screening and molecular tests to detect the genetic point mutation (C-A transversion) at position 3284 in exon 29 of the PKD1 gene have been employed routinely in the diagnosis of the feline disease (LYONS et al., 2004). Interestingly, cardiac abnormalities have been rarely described in cats with ADPKD; although cases involving LVH and biventricular cardiac dilation (BILLER et al., 1990; EATON et al., 1997), cardiomyopathy of unknown origin (BOSJE et al., 1998), minor increases in mean arterial pressure, endocardial echogenicity, restrictive diastolic filling pattern, mild dilatation of the left ventricle, and slight mitral valve regurgitation (PEDERSEN et al., 2013) have been reported. The purpose of this study was to assess the echo- and electrocardiographic profiles of ADPKD-affected Persian cats.

\section{MATERIALS AND METHODS}

An observational, transversal and descriptive study was carried out with a population comprised 82 Persian cats, males and females, originated from ten households. Initially, abdominal ultrasound scans were performed using an ultrasound machine with multifrequency $(6-10 \mathrm{MHz})$ microconvex or multifrequency $(7.5-12 \mathrm{MHz})$ linear transducers (Logiq 7, GE Healthcare, Chalfont St Giles, UK). From those animals, twelve (14.6\%) were diagnosed with ADPKD through abdominal ultrasonography, which revealed the presence of four to more than ten renal cysts per animal. Thereafter, genetic analysis confirmed the presence of the C-A mutation in exon 29 of the PKDl gene in all animals, which was detected on DNA samples extracted from blood by polymerase chain reaction-restriction fragment length polymorphism (PCR-RFLP) (GUERRA et al., 2019). For comparison, twelve age and sex-matched Persian cats, with no evidences of systemic disease, were randomly selected as control group (non-ADPKD cats). All of heathy animals did not exhibit renal cysts and were negative for the referred $P K D 1$ mutation.

After ultrasonography and genetic screening, each of 24 Persian cats underwent a complete physical examination that included measurement of systolic blood pressure (SBP) together 
with electrocardiogram (ECG), echocardiographic, hematological and biochemical analyses, carried out according to standard methodologies (TILLEY, 1992; BROWN et al., 2007; BONAZZI et al., 2009; BOON, 2011; GUERRA et al., 2015; 2019). Clinical signs evaluated included emaciation, dyspnea, cough, fatigue, exercise intolerance, cyanosis, pre-syncope or syncope, edema or ascites, and convulsion.

Values of SBP were obtained by Doppler ultrasonography linked to an aneroid sphygmomanometer (Medmega DV610B instrument, Nova Med Tec, São Paulo, Brazil), according to the methodology previously described (LITTMAN, 2000). Briefly, cats were placed in a quiet and undisturbed room prior to measurement of SBP, in order to acclimatize them to the new environment and strange people (BELEW et al., 1999). Five consecutive measurements were performed and the results were expressed as arithmetic means. The ECG data were acquired using a standard six-lead device (Ecafix ECG6, Transform, São Paulo, Brazil), with nonsedated animals positioned in right lateral or sternal recumbency, evaluating the bipolar leads I, II and III and the unipolar leads aVR, aVL and VF, as well as the precordial leads CV5RL (rV2), CV6LL (V2), CV6LU (V4) and v10 at a recording speed of $25 \mathrm{~mm} / \mathrm{s}$ and a calibration of $1 \mathrm{mV}$ equal to $1 \mathrm{~cm}$. Bipolar II lead was recorded at a speed of $50 \mathrm{~mm} / \mathrm{s}$. ECG traces were examined to rhythm and waveform according to standard procedures (TILLEY et al., 1992).

Blood was collected by jugular venipuncture and submitted to: (i) hematological examination - complete blood count $(\mathrm{CBC})$, white blood cell count (WBC), hemoglobin $(\mathrm{Hb})$ and blood urea nitrogen (BUN); (ii) biochemical assay creatinine, alanine aminotransferase (ALT), aspartate aminotransferase (AST), alkaline phosphatase (ALP), total protein, thyroxine (T4), sodium, calcium, potassium and phosphorus; and (iii) molecular analysis (PCR-RFLP).

Echocardiographic examinations were carried out with cats in right and left lateral recumbency using an ultrasound machine (Vivid-i, GE Healthcare, Chalfont St Giles, UK) with 8 and $12 \mathrm{MHz}$ multifrequency phased array transducers as recommended by the Echocardiography Committee of the Specialty of Cardiology, American College of Veterinary Internal Medicine (THOMAS et al., 1993) and by the American Society of Echocardiography (BOON, 2011). At least three determinations were performed for each parameter evaluated in the different phases of the cardiac cycle, considering the average of the values obtained. Echocardiograms were analyzed using the commercial software package supplied with the system, and diagnosis was based on current literature (FERASIN, 2009). Images for the measurement of the left ventricle were acquired in the right parasternal window, cross-sectioned, at the time of insertion of the tendinous strings in the papillary muscles (M mode). The occurrence of myocardial hypertrophy was defined when the diastolic thickness of the interventricular septum (IVSd) and/or the left ventricular free wall (LVFWd) was equal to or greater than $0.6 \mathrm{~cm}$. Cats with diastolic thicknesses less than $0.5 \mathrm{~cm}$ were considered normal. Concentric hypertrophy was considered symmetrical when the IVSd/LVFWd ratio was between 0.7 and 1.3. In the presence of asymmetric hypertrophy, segmental hypertrophy was measured by the two-dimensional mode. Measurements of the diameter of the aortic root (Ao) and the diameter of the left atrium (LA) were performed using the two-dimensional mode, right parasternal window, cross section, in the cardiac base region. An increase in AE was considered when the AE/Ao ratio was greater than 1.5 (WESS et al., 2010). The left atrial-to-aortic root diameter ratio (LA/Ao) was established by echocardiography from the right parasternal short-axis heart base view. Doppler echocardiography (color, pulsed wave and continuous wave) was employed to characterize flow disturbances (KITTLESON et al., 1999).

All statistical analyses were carried out using R-statistical environment software (http://rproject.org/). Continuous variables are presented as mean \pm standard deviation (and median, minimummaximum). The Shapiro-Wilk test was used to test data normality. Mann-Whitney or Student's $t$ tests were used to compare the means or the medians, respectively, of continuous variables between two groups (ADPKD and non-ADPKD cats). Correlations between variables that were not normally distributed were investigated by means of the Spearman rank correlation test. To assess the difference in categorical variables between groups, Fisher's exact test was used. In all analyses, a twotailed alternative hypothesis was employed, and the level of significance was set at $5 \%$.

\section{RESULTS}

Of the 24 Persian cats enrolled in the study, $10(41.67 \%)$ were male and $14(58.33 \%)$ were female. Five males (20.84\%) and four females $(16.67 \%)$ were sexually intact, whereas 5 males $(20.84 \%)$ and 10 females had been neutered $(41.67 \%)$. The mean body weight of males was $4.18 \pm 1.54 \mathrm{~kg}$ (range 2.0 to 6.15 $\mathrm{kg}$ ) and that of females was $3.57 \pm 1.10 \mathrm{~kg}$ (range 2.0 
to $4.80 \mathrm{~kg}$ ), but these values were not significantly different $(\mathrm{P}=0.445)$. The mean age of the entire cat population was $92.46 \pm 38.92$ months (range 28 to 162 months), while the mean ages of males and females $(94.9 \pm 42.3$ vs. $90.7 \pm 37.9$ months, respectively) did not significantly differ $(\mathrm{P}=0.802)$. There were no significant differences between the ADPKD and non-ADPKD cats in regard to gender (Male:Female ratio: $6 / 6$ vs. $4 / 8, \mathrm{P}=0.691)$, age $(96.0 \pm 46.9 v s$. $88.92 \pm 30.55$ months, $\mathrm{P}=0.666)$ and body weight $(3.75 \pm 1.65$ vs. $4.17 \pm 0.80 \mathrm{~kg}, \mathrm{P}=0.475)$. The most common clinical signs in the ADPKD population were emaciation $(20.0 \%)$ and fatigue (13.3\%). However, there were no statistical differences between the groups regarding the frequency of the clinical signs (data not shown). Also, there were no significative differences regarding hematological and biochemical parameters between ADPKD and nonADPKD cats, including T4 levels (Table 1). None of the animals manifested symptoms of hypothyroidism or hyperthyroidism.

Cardiovascular evaluations showed that all animals were normotensive, and no statistical differences were observed between the groups with respect to systolic blood pressure. Also, there was no difference in heart rate (HR) between ADPKD and non-ADPKD cats (Table 2). Presence of left-sided heart abnormalities was observed in $3 / 12(25 \%)$ and $6 / 12(50 \%)$ cats in ADPKD and
non-ADPKD groups, respectively. No statistical difference was observed regarding the frequency of these alterations $(P=0.126)$. The ECG traces of all animals exhibited normal sinus rhythms, with the exception of $1 / 12(8.3 \%)$ cat in the ADPKDaffected group that presented sinus tachycardia, considering cases in which HR was greater than 240 bpm (TILLEY et al., 1992). No animals revealed supraventricular arrhythmias.

No differences were observed between the two groups with respect to heart rate, P-wave width, PR interval, QRS interval, R-wave amplitude, QT interval and R-wave or S-wave amplitudes in precordial chest leads CV5RL (rV2), CV6LL (V2) and CV6LU (V4). P-wave amplitudes on lead II were slightly elevated in ADPKD-cats, especially in those with concurrent $\mathrm{LVH}(0.200 \pm 0.054 \mathrm{mV})$; however, there is no statistical difference $(\mathrm{P}=0.069)$ (Table 2 ). With respect to defects in the impulse conduction system, an incomplete right bundle branch block was observed in 3/12 (25\%) animals of the non-ADPKD group and in $2 / 12(16.67 \%)$ animals of ADPKD group, with no statistical difference $(P=1.000)$. A left anterior fascicular block and a first-degree atrioventricular block were detected in one animal with ADPKD and LVH, but differences regarding the occurrence of these defects were not significant $(\mathrm{P}=$ $1.000)$ between the two groups. Abnormal ventricular repolarization and ventricular premature complexes

Table 1 - Hematological and biochemical profiles of Persian cats enrolled in the study.

\begin{tabular}{|c|c|c|c|}
\hline Parameters & Non-ADPKD cats $(n=12)$ & ADPKD cats $(n=12)$ & P-value \\
\hline $\mathrm{Hb}(\mathrm{g} / \mathrm{dL})$ & $13.93 \pm 1.64(14.10,13.48-16.00)$ & $13.95 \pm 1.19(14.39,12.3-15.83)$ & 0.600 \\
\hline WBC $\left(\mathrm{mm}^{3} \times 10^{3}\right)$ & $11.96 \pm 5.99(10.15,4.60-28.70)$ & $12.26 \pm 5.94(14.22,4.10-20.50)$ & 0.926 \\
\hline BUN (mg/dL) & $47.89 \pm 8.26(45.25,38.30-58.00)$ & $47.41 \pm 12.89(47.20,28.70-74.90)$ & 0.915 \\
\hline Creatinine (mg/dL) & $1.12 \pm 0.27(1.19 ; 0.86-1.60)$ & $1.20 \pm 0.24(1.24,0.78-1.61)$ & 0.745 \\
\hline ALT (UI/dL) & $58.00 \pm 47.70(42.80,28.0-197.10)$ & $42.70 \pm 19.99(31.00,24.60-83.80)$ & 0.374 \\
\hline AST (UI/dL) & $21.48 \pm 9.20(18.45,11.70-46.80)$ & $17.16 \pm 5.21(16.00,11.1-26.30)$ & 0.126 \\
\hline ALP (UI/ dL) & $19.92 \pm 6.91(21.35,10.70-29.60)$ & $17.10 \pm 8.31(15.40,9.20-35.82)$ & 0.407 \\
\hline Protein $(\mathrm{g} / \mathrm{dL})$ & $6.79 \pm 1.36(7.23,3.67-8.54)$ & $7.23 \pm 0.34(7.13,6.65-7.61)$ & 0.365 \\
\hline $\mathrm{Ca}(\mathrm{mg} / \mathrm{dL})$ & $10.51 \pm 0.82(11.8,869-11.80)$ & $10.49 \pm 1.36(10.23,8.88-12.71)$ & 0.964 \\
\hline $\mathrm{P}(\mathrm{mg} / \mathrm{dL})$ & $4.46 \pm 0.84(4.39,2.90-6.17)$ & $4.68 \pm 0.83(4.86,2.65-5.62)$ & 0.262 \\
\hline $\mathrm{Na}(\mathrm{mEq} / \mathrm{dL})$ & $154.93 \pm 2.81(155.30,150.40-156.40)$ & $153.03 \pm 2.06(152.60,150.80-156.00)$ & 0.156 \\
\hline $\mathrm{K}(\mathrm{mEq} / \mathrm{dL})$ & $4.64 \pm 0.59(4.54,3.40-5.51)$ & $4.62 \pm 0.39(4.70,3.90-5.21)$ & 0.947 \\
\hline $\mathrm{T} 4(\mu \mathrm{g} / \mathrm{dL})$ & $1.84 \pm 0.33(1.90,1.37-2.39)$ & $1.56 \pm 0.18(1.68,1.24-1,74)$ & 0.117 \\
\hline
\end{tabular}

Hb, Hemoglobin; WBC, White blood cells; BUN, Blood urea nitrogen; ALT, Alanine aminotransferase; AST, Aspartate aminotransferase; ALP, Alkaline phosphatase; Ca; Calcium; P; Phosphorus; Na; Sodium; K; Potassium; T4, Thyroxine. *Student's $t$ test or Mann-Whitney test $(\mathrm{P}<0.05)$. Continuous variables are expressed as mean \pm standard deviation (median, minimum-maximum). 
Table 2 - Cardiovascular and ECG profiles of Persian cats enrolled in the study.

\begin{tabular}{lccc}
\hline Parameters & Non-ADPKD cats $(\mathrm{n}=12)$ & ADPKD cats $(\mathrm{n}=12)$ & P-value \\
\hline HR $(\mathrm{bpm})$ & $197.00 \pm 24.91(200.00,160.00-230.00)$ & $194.17 \pm 27.12(195.00,160.00-260.00)$ & 0.757 \\
SBP $(\mathrm{mmHg})$ & $146.25 \pm 20.26(147.00,118.00-180.00)$ & $143.67 \pm 15.86(143.00,120.00-166.00)$ & 0.731 \\
P-wave width (sec) & $0.032 \pm 0.006(0.030,0.020-0.040)$ & $0.031 \pm 0.005(0.030-0.020-0.040)$ & 0.772 \\
P-wave amplitude (mV) & $0.125 \pm 0.045(0.150,0.050-0.200)$ & $0.170 \pm 0.058(0.175,0.100-0.300)$ & 0.069 \\
PR interval (sec) & $0.075 \pm 0.007(0.075,0.060-0.090)$ & $0.075 \pm 0.011(0.080,0.060-0.100)$ & 1.000 \\
QRS interval (sec) & $0.027 \pm 0.006(0.030,0.020-0.040)$ & $0.030 \pm 0.011(0.030,0.020-0.060)$ & 0.644 \\
R-wave amplitude (mV) & $0.170 \pm 0.202(0.100,0.050-0.700)$ & $0.279 \pm 0.310(0.175,0.050-1.100)$ & 0.418 \\
QT interval (sec) & $0.135 \pm 0.019(0.125,0.120-0.180)$ & $0.144 \pm 0.019(0.145,0.120-0.180)$ & 0.225 \\
\hline
\end{tabular}

HR, Heart rate; SBP, Systolic blood pressure; bpm, beats per minute; mmHg, millimeter of mercury; mm, millimeter; sec, seconds; mV, millivolts. "Student's $t$ test or Mann-Whitney test $(\mathrm{P}<0.05)$. Continuous variables are expressed as mean \pm standard deviation (median, minimum-maximum).

were observed, respectively, in two (16.67\%) and one (8.33\%) ADPKD-cats with LVH.

Echocardiographic measurements revealed that $3 / 12(25.0 \%)$ and $3 / 12(25.0 \%)$ animals enrolled in the ADPKD and non-ADPKD groups, respectively, displayed left ventricular hypertrophy, which involve the basal septum adjacent to the left ventricular outflow tract and/or involving portions of the ventricular septum as well as the contiguous anterolateral and posterior free walls. No statistical difference was observed between the proportions of LVH in these two groups ( $\mathrm{P}=0.400)$. AoIVSd, IVSd, LVFWd and LVIDd thicknesses, and the IVSd/LVFW ratio did not significantly differ between the groups. Additionally, basal interventricular septal thickness at end-diastole showed no statistical difference in ADPKD-affected animals $(\mathrm{P}=0.084)$. Left ventricular ejection fraction (LVEF) and shortening fraction (LVSF) also did not differ between ADPKD and nonADPKD cats. No significant differences related to the remaining echocardiographic parameters were observed between the two groups either. Similar to AoIVSd, aortic artery flow velocity showed no difference in the ADPKD group $(\mathrm{P}=0.064)$ (Table 3$)$.

Additionally, neither a significant difference in SBP between ADPKD-affected cats with and without LVH $(\mathrm{P}=0.902)$ nor a significant correlation between left ventricular wall thickness and SPB (IVSd, P = 0.843, r = 0.043; LVFWd, P = $0.171, r=-0.289)$ were observed.

Within the ADPKD group, 3/12 (25.0\%) animals exhibited mild insufficiency of the mitral and tricuspid valves, and $1 / 12(8.3 \%)$ exhibited only mitral valve insufficiency associated with increased ventricular septum echogenicity. Also, one $(8.3 \%)$ animal presented mild obstruction of the left ventricular outflow tract. Among non-ADPKD cats, only $1 / 12(8.33 \%)$ presented mild mitral valve insufficiency. No significant differences were observed between the two groups with regard to the frequency of appearance or movement of the valve leaflets $(P=0.316)$.

\section{DISCUSSION}

The aim of the current study was to evaluate the cardiac phenotype of Persian cats diagnosed with ADPKD. In humans, $89 \%$ of ADPKD-patients that died due cardiac causes exhibited LVH, a manifestation that constitutes an important risk factor for sudden cardiac death (FICK et al., 1995). Various studies involving ADPKD in humans and experimental animal models have shown that both hypertension and activation of the renin-angiotensin system (RAS) contribute to the development of LVH (ECDER et al., 1999; PHILLIPS et al., 2007). Cyst expansion and local hypoperfusion activates intrarenal RAS causing hypertension, while increased pressure load stimulates myocyte hypertrophy, collagen formation and fibroblast proliferation, thereby remodeling the myocardium with a disproportionate amount of fibrous tissue (CHAPMAN et al. 1997; KAHAN et al., 2005; FONSECA et al., 2014).

Our results revealed; however, no significant differences between the two groups of animals in regard to SBP; only one animal in nonADPKD group presented SPB of $180 \mathrm{mmHg}$, not associated with LVH. It is unclear why ADPKD cats 
Table 3 - Echocardiographic profile of Persian cats enrolled in the study.

\begin{tabular}{|c|c|c|c|}
\hline Parameters & Non-ADPKD cats $(\mathrm{n}=12)$ & ADPKD cats $(n=12)$ & P-value \\
\hline AoIVSd (cm) & $0.515 \pm 0.062(0.490 ; 0.450-0.620)$ & $0.605 \pm 0.158(0.555 ; 0.400-0.850)$ & 0.084 \\
\hline IVSd $(\mathrm{cm})$ & $0.478 \pm 0.062(0.480 ; 0.330-0.580)$ & $0.540 \pm 0.136(0.500 ; 0.330-0.800)$ & 0.165 \\
\hline LVFWd (cm) & $0.442 \pm 0.046(0.445 ; 0.360-0.540)$ & $0.482 \pm 0.106(0.470 ; 0.310-0.760)$ & 0.193 \\
\hline IVSd/LVFWd & $1.080 \pm 0.090(1.089 ; 0.916-1.260)$ & $1.120 \pm 0.157(1.077 ; 0.952-1.510)$ & 0.464 \\
\hline LVIDd (cm) & $1.367 \pm 0.151(1.305 ; 1.170-1.620)$ & $1.324 \pm 0.211(1.360 ; 1.030-1.680)$ & 0.644 \\
\hline LVIDs $(\mathrm{cm})$ & $0.614 \pm 0.144(0.595 ; 0.430-0.930)$ & $0.610 \pm 0.172(0.595 ; 0.370-0.930)$ & 0.949 \\
\hline Shortening fraction $(\%)$ & $55.25 \pm 0.067(55.00 ; 42.00-63.00)$ & $54.58 \pm 0.085(54.50 ; 35.00-0.660)$ & 0.834 \\
\hline Ejection fraction & $0.882 \pm 0.051(0.885 ; 0.770-0.940)$ & $0.874 \pm 0.072(0.885 ; 0.680-0.950)$ & 0.862 \\
\hline Ao $(\mathrm{cm})$ & $0.889 \pm 0.089(0.905 ; 0.710-1.000)$ & $0.915 \pm 0.076(0.995 ; 0.760-1.120)$ & 0.540 \\
\hline $\mathrm{LA}(\mathrm{cm})$ & $1.100 \pm 0.150(1.100 ; 0.800-1.400)$ & $1.181 \pm 0.254(1.155 ; 0.840-1.610)$ & 0.358 \\
\hline LA/Ao ratio & $1.238 \pm 0.124(1.219 ; 1.031-1.489)$ & $1.294 \pm 0.256(1.071 ; 0.970-1.892)$ & 0.513 \\
\hline Aortic FV (m/s) & $0.919 \pm 0.106(0.900 ; 0.760-1.070)$ & $1.193 \pm 0.451(1.045 ; 0.720-2.190)$ & 0.064 \\
\hline Aortic PG (mmHg) & $3.423 \pm 0.787(3.285 ; 2.300-4.600)$ & $6.430 \pm 5.16(4.400 ; 2.050-19.18)$ & 0.141 \\
\hline Pulmonary artery FV (m/s) & $0.998 \pm 0.114(0.970 ; 0.840-1.170)$ & $0.918 \pm 0.245(1.015 ; 0.580-1.390)$ & 0.317 \\
\hline Pulmonary artery PG (mmHg) & $4.033 \pm 1.929(3.770 ; 2.800-5.500)$ & $3.619 \pm 1.938(3.310 ; 1.370-7.740)$ & 0.511 \\
\hline E-wave $(\mathrm{m} / \mathrm{s})$ & $0.702 \pm 0.113(0.690 ; 0.540-0.890)$ & $0.765 \pm 0.275(0.765 ; 0.410-1.290)$ & 0.474 \\
\hline E-wave deceleration time (ms) & $63.00 \pm 16.43(59.50 ; 45.00-91.00)$ & $57.17 \pm 24.09(58.00 ; 18.00-90.00)$ & 0.496 \\
\hline A-wave $(\mathrm{m} / \mathrm{s})$ & $0.554 \pm 0.163(0.550 ; 0.340-0.870)$ & $0.633 \pm 0.178(0.560 ; 0.440-0.940)$ & 0.344 \\
\hline $\mathrm{E} / \mathrm{A}$ ratio & $1.286 \pm 0.405(1.230 ; 0.690-1.830)$ & $1.186 \pm 0.662(0.915 ; 0.440-2.804)$ & 0.377 \\
\hline IVRT (ms) & $47.58 \pm 3.90(48.00 ; 41.00-52.00)$ & $47.42 \pm 9.61(45.00 ; 28.00-65.00)$ & 0.583 \\
\hline
\end{tabular}

AoIVSd, Basal interventricular septal thickness at end-diastole near the left ventricular outflow tract; IVSd, Interventricular septal thickness at end-diastole; LVFWd, Left ventricular freewall thickness at end-diastole; LVIDd, Left ventricular internal diameter at enddiastole; LVIDs, Left ventricular internal diameter at end-systole; Ao, Aorta diameter at right transverse view in two-dimensional echocardiography; LA, Left atrium diameter at right transverse view in two-dimensional echocardiography; FV, Flow velocity; PG, Pressure gradient; IVRT, Isovolumetric relaxation time. Student's $t$ test or Mann-Whitney test $(\mathrm{P}<0.05)$. Continuous variables are expressed as mean \pm standard deviation (median, minimum-maximum).

did not reproduce the hypertensive pattern displayed by $P k d 1$-deficient cystic mice (FONSECA et al., 2014). A potentially lower renal cystic burden in cats than in the evaluated mice should be considered as a possible contributor to such a blood pressure behavior. Few reports are available addressing hypertension and alterations in hormonal determinants that regulate blood pressure in cats affected by ADPKD. However, PERDERSEN et al. (2003) showed that all cats with mild and severe forms of the disease $(n=14)$ exhibited higher mean arterial pressure and a trend towards higher SBP compared with healthy control animals. None of the cats; however, showed echocardiographic evidence of cardiac hypertrophy. Moreover, SNYDER et al. (2001) described that the frequency of LVH in hypertensive cats with systemic arterial pressure $>170 \mathrm{~mm} \mathrm{Hg}$ was around $74 \%$.

CHAPMAN et al. (1997) carried out echocardiographic tests in humans (77 healthy subjects and 116 adults diagnosed with ADPKD) and reported that $\mathrm{LVH}$ was present in $23 \%$ of normotensive ADPKD patients and $16 \%$ of the healthy controls; although, these parameters were not statistically significant. It is interesting to notice that, in both groups, presence of LVH did not correlate with blood pressure. Normotensive ADPKD adults; however, showed increased left ventricular mass index compared to controls. Similar findings have been reported by other studies (TIMIO et al., 1992; SAGGAR-MALIK et al., 1994). Moreover, increased left ventricular mass index has been reported in young normotensive humans with ADPKD and well-preserved renal function, and is apparently associated with biventricular diastolic and endothelial dysfunction, increased carotid intimamedia thickness and impaired coronary flow velocity reserve, suggesting that cardiovascular involvement starts at early stages of ADPKD (MARTINEZVEA et al., 2000; 2004). Such cardiac alterations have been associated with hemodynamic factors, including lower nocturnal fall in blood pressure rhythm (VALERO et al., 1999). In the present study, 
no significant differences were observed between the two groups of animals with respect to systolic and diastolic function as well as valve morphology and movement. The lack of difference in LVEF and LVSF observed between ADPKD and non-ADPKD animals did not reproduce previous findings of systolic dysfunction in Pkdl-deficient mice (BALBO et al., 2016). We presently have no robust explanation for this distinct heart functional pattern; however, it is possible that the allele harboring the $P K D 1$ mutation common to all affected cats exerts a hypomorphic effect on the feline heart. WANG et al. (2000) reported the occurrence of endothelial dysfunction and reduced nitric oxide synthase (NOS) activity in humans diagnosed with ADPKD even before the development of hypertension or renal insufficiency; although the abnormalities were shown to be more severe in the setting of hypertension.

Hypertrophic cardiomyopathy (HCM), the most common type of cardiomyopathic phenotype in cats, is characterized by diffuse or regional increased left ventricle (LV) wall thickness with a nondilated LV chamber. The HCM remains a major source of feline morbidity and mortality, with congestive heart failure and arterial thromboembolism as the most common cause of clinical signs and sudden death in this species (LUIS FUENTES et al., 2020). In some breeds, such as Maine Coon and Ragdoll cats, HCM is an autosomal dominant inherited disease caused by a mutation in the gene that encodes the cardiac myosin binding protein C (MYBPC3) (MEURS et al., 2005; 2007). Although, there is some evidence of inherited familial HCM in Persian cats, inherited mutations have not yet been reported in this breed (RUSH et al., 2002). In the present study, it was not possible to ascertain whether HCM was linked to ADPKD in Persian cats or if these two separate inherited diseases emerged concomitantly, since three animals in nonADPKD group also displayed asymmetric LVH.

This study has some limitations; however, which included the observational nature of the investigation, the definition of hypertension in cats and the under-representation of animals within the groups. Nevertheless, the number of cats employed herein was equivalent to other ADPKD studies (PEDERSEN et al., 2013; LEE et al., 2010). In humans, some echocardiographic measurements, including LV free-wall thickness, can be influenced by age. When analyzing cats; therefore, comparisons should also be made using age-matched controls (GERSTENBLITH et al., 1977). In this context, we have carefully selected animals of comparable age and sex for non-ADPKD and ADPKD groups. The definition of systolic hypertension in cats, in turn, is still debated in veterinary medicine; although, the American College of Veterinary Internal Medicine consensus panel considers an SBP between 170 and $180 \mathrm{mmHg}$ a risky condition to target organ damage (JEPSON, 2011). Of note, none of the animals had concurrent clinical signs that could support the diagnosis of hypertension. In this setting, abnormal high arterial pressure was not considered the cause of LVH in these animals.

\section{CONCLUSION}

Based on the feline population employed herein, our study revealed that Persian cats with ADPKD do not reproduce the functional and structural cardiac phenotype reported in human patients with this disease nor the heart dysfunction observed in $P k d 1$ deficient mouse models. Further studies with largescale cohort of Persian cats; however, are necessary to distinguish the possibilities of a true linkage between ADPKD and LVH and an association between two distinct diseases in this breed. Differential diagnosis is important to pet owners because it allows early detection and treatment of disease complications.

\section{ACKNOWLEDGEMENTS}

The authors wish to thank Associação dos Criadores de Gato Persa (São Paulo, SP, Brazil) in facilitating communication with the owners of the cats. The study was funded by the Fundação de Amparo à Pesquisa do Estado de São Paulo (FAPESP, grants $\mathrm{n}^{\mathrm{o}}$. 12/19614-6, 12/04990-2 and 13/06471-5), Conselho Nacional de Desenvolvimento Cientifico e Tecnológico $\left(\mathrm{CNPq}\right.$, grants $\mathrm{n}^{\circ}$ 311929/2015-0 and 310557/2019-4) and by the Coordenação de Aperfeiçoamento de Pessoal de Nível Superior (CAPES), Brasil - Finance code 001. This work was also supported by European Investment Funds by FEDER/COMPETE/POCI - Operacional Competitiveness and Internacionalization Programme, under Project POCI-01-0145-FEDER-006958 and National Funds by FCT - Portuguese Foundation for Science and Technology, under the project UID/AGR/04033/2013.

\section{BIOETHICS AND BIOSSECURITY COMMITTEE APPROVAL}

The owners were thoroughly informed about the research aims and protocols, and written informed consent was obtained from the owner of each pet prior the investigation. This study was approved by the Institution's Ethical Committee of the Faculdade de Medicina Veterinária e Zootecnia da Universidade de São Paulo (Protocol no ${ }^{\circ}$ 1812010514) and it was conducted in accordance with the guidelines of Colégio Brasileiro de Experimentação Animal (COBEA).

\section{DECLARATION OF CONFLICT OF INTERESTS}

The authors declare no conflict of interest. The founding sponsors had no role in the design of the study; in the 
collection, analyses, or interpretation of data; in the writing of the manuscript, and in the decision to publish the results.

\section{AUTOHR'S CONTRIBUTIONS}

BC, JMG, LFO, FLQ and MHMAL conceived and designed experiments. JMG performed the laboratory analyzes, statistical analyzes of experimental data and the manuscript draft. NCC and GGL performed the laboratory analyzes. MFF performed the ultrasonography. AP and RBP performed the ECG and the echocardiography. AGTD performed the clinical evaluation and samples collection. All authors critically reviewed the manuscript and approved the final version.

\section{REFERENCES}

BASTOS, A.P.; ONUCHIC, L.F. Molecular and cellular pathogenesis of autosomal dominant polycystic kidney disease. Brazilian Journal of Medical and Biological Research, v.44, n.7, p.606-617, 2011. Available from: <http://www.ncbi.nlm.nih.gov/pubmed/21625823>. Accessed: Apr. 13, 2014. doi: 10.1590/s0100-879x2011007500068.

BALBO, B.E. et al. Cardiac dysfunction in Pkd1-deficient mice with phenotype rescue by galectin-3 knockout. Kidney International, v.90, n.3, p.580-597, 2016. Available from: <https://www.ncbi. nlm.nih.gov/pubmed/27475230>. Accessed: Dec. 21, 2019. doi: 10.1016/j.kint.2016.04.028.

BELEW, A.M. et al. Evaluation of the white-coat effect in cats. Journal of Veterinary Internal Medicine, v.13, n.2, p.134-142, 1999. Available from: <https://www.ncbi.nlm. nih.gov/pubmed/10225603>. Accessed: Jan. 12, 2016. doi: 10.1892/0891-6640(1999)013<0134: eotwce $>2.3$. co;2.

BILLER, D.S. et al. Polycystic kidney disease in a family of Persian cats. Journal of the American Veterinary Medical Association, v.196, n.8, p.1288-1290, 1990. Available from: <http://www.ncbi. nlm.nih.gov/pubmed/2185204>. Accessed: Feb. 2, 2014. PubMed PMID: 2185204.

BONAZZI, M. et al. Comparison between ultrasound and genetic testing for the early diagnosis of polycystic kidney disease in Persian and Exotic Shorthair cats. Journal of Feline Medicine and Surgery, v.11, n.6, p.430-434, 2009. Available from: <http:// www.ncbi.nlm.nih.gov/pubmed/19046910>. Accessed: Oct. 3, 2011. doi: 10.1016/j.jfms.2008.10.003.

BOON, J.A. Veterinary Echocardiography. 2.ed. Ames, Iowa : Wiley-Blackwell, 2011. 610p.

BOSJE, J.T. et al. Polycystic kidney and liver disease in cats. The Veterinary Quarterly, v.20, n.4, p.136-139, 1998. Available from: $<$ https://www.ncbi.nlm.nih.gov/pubmed/9810628>. Accessed: Jul. 22, 2012. doi: 10.1080/01652176.1998.9694858.

BROWN, S. et al. Guidelines for the identification, evaluation, and management of systemic hypertension in dogs and cats. Journal of Veterinary Internal Medicine, v.21, n.3, p.542-558, 2007. Available from: <http://www.ncbi.nlm. nih.gov/pubmed/17552466>. Accessed: Jun. 22, 2014. doi: 0.1892/0891-6640(2007)21[542:gftiea]2.0.co;2.

CORNEC-LE GALL, E. et al. Genetic complexity of autosomal dominant polycystic kidney and liver diseases. Journal of the American Society of Nephrology, v.29, n.1, p.1323, 2018. Available from: <https://www.ncbi.nlm.nih.gov/ pubmed/29038287>. Accessed: Dec. 21, 2019. doi: 10.1681/ ASN.2017050483.

CHAPMAN, A.B. et al. Left ventricular hypertrophy in autosomal dominant polycystic kidney disease. Journal of the American Society of Nephrology, v.8, n.8, p.1292-1297, 1997. Available from: $\quad<$ http://www.ncbi.nlm.nih.gov/pubmed/9259356>. Accessed: Jun. 2, 2014. PubMed PMID: 9259356.

DELMAS, P. The gating of polycystin signaling complex. Biological Research, v.37, n.4, p.681-691, 2004. Available from: $<$ http://www.ncbi.nlm.nih.gov/pubmed/15709698>. Accessed: Apr. 13, 2014. doi: 10.4067/s0716-97602004000400026.

EATON, K.A. et al. Autosomal dominant polycystic kidney disease in Persian and Persian-cross cats. Veterinary Pathology, v.34, n.2, p.117-126, 1997. Available from: <http://www.ncbi. nlm.nih.gov/pubmed/9066078 $>$. Accessed: Feb. 13, 2012. doi: $10.1177 / 030098589703400204$.

ECDER, T. et al. Reversal of left ventricular hypertrophy with angiotensin converting enzyme inhibition in hypertensive patients with autosomal dominant polycystic kidney disease. Nephrology Dialysis Transplantation, v.14, n.5, p.1113-1116, 1999. Available from: $\quad<$ https://www.ncbi.nlm.nih.gov/pubmed/10344347>. Accessed: Jun. 22, 2014. doi: 10.1093/ndt/14.5.1113.

ECDER, T. Cardiovascular complications in autosomal dominant polycystic kidney disease. Current Hypertension Reviews, v.9, n.1, p.2-11, 2013. Available from: <https://www.ncbi.nlm. nih.gov/pubmed/23971638>. Accessed: Ago. 2, 2015. doi: 10.2174/1573402111309010002.

FERASIN, L. Feline myocardial disease 2: diagnosis, prognosis and clinical management. Journal of Feline Medicine and Surgery, v.11, n.3, p.183-194, 2009. Available from: <https:// www.ncbi.nlm.nih.gov/pubmed/19237134>. Accessed: May, 12, 2014. doi: 10.1016/j.jfms.2009.01.002.

FICK, G.M. et al. Causes of death in autosomal dominant polycystic kidney disease. Journal of the American Society of Nephrology, v.5, n.12, p.2048-2056, 1995. Available from: <http://www.ncbi. nlm.nih.gov/pubmed/7579053>. Accessed: Jul. 12, 2014. doi: PubMed PMID: 7579053.

FONSECA, J.M. et al. Renal cyst growth is the main determinant for hypertension and concentrating deficit in Pkd1-deficient mice. Kidney International, v.85, n.5, p.1137-1150, 2014. Avalaible from: <https://www.ncbi.nlm.nih.gov/pubmed/24429399>. Accessed: Dec. 19, 2019. doi: 10.1038/ki.2013.501.

GERSTENBLITH, G. et al. Echocardiographic assessment of a normal adult aging population. Circulation, v.56, n.2, p.273278, 1977. Available from: <https://www.ncbi.nlm.nih.gov/ pubmed/872321>. Accessed: Nov. 16, 2014. doi: 10.1161/01. cir.56.2.273.

GUERRA, J.M. et al. Congenital hepatic fibrosis and polycystic kidney disease not linked to $\mathrm{C}>\mathrm{A}$ mutation in exon 29 of PKD1 in a Persian cat. Journal of Feline Medicine and Surgery open reports, v.1, n.2, 2055116915619191, 2015. Available from: $<$ https://www.ncbi.nlm.nih.gov/pubmed/28491400>. Accessed: Dec. 18, 2016. doi: 10.1177/2055116915619191. 
GUERRA, J.M. et al. Age-based ultrasonographic criteria for diagnosis of autosomal dominant polycystic kidney disease in Persian cats. Journal of Feline Medicine and Surgery, v. 21 n.2, p.156-164, 2019. Available from: <https://www.ncbi.nlm. nih.gov/pubmed/29652208>. Accessed: Jan. 28, 2019. doi: $10.1177 / 1098612 \mathrm{X} 18764591$.

JEPSON, R.E. Feline systemic hypertension: Classification and pathogenesis. Journal of Feline Medicine and Surgery, v.13, n.1, p.25-34, 2011. Available from: <https://www.ncbi.nlm.nih. gov/pubmed/21215946>. Accessed: Mar. 23, 2014. doi: 10.1016/j. jfms.2010.11.007.

KAHAN, T. Left ventricular hypertrophy in hypertension: its arrhythmogenic potential. Heart, v.91, n.2, p.250-256, 2005. Available from: <https://www.ncbi.nlm.nih.gov/ pubmed/15657259>. Accessed: Nov. 25, 2014. doi: 10.1136/ hrt.2004.042473.

KITTLESON, M.D. et al. Familial hypertrophic cardiomyopathy in maine coon cats: an animal model of human disease. Circulation, v.99, n.24, p.3172-3180, 1999. Available from: <https://www.ncbi nlm.nih.gov/pubmed/10377082>. Accessed: Jun. 2, 2014. doi: 10.1161/01.cir.99.24.3172.

LEE, Y.J. et al. Molecular detection of autosomal-dominant feline polycystic kidney disease by multiplex amplification refractory mutation system polymerase chain reaction. Journal of Veterinary Diagnostic Investigation, v.22, n.3, p.424-428, 2010. Available from: $\quad<$ https://www.ncbi.nlm.nih.gov/pubmed/20453219>. Accessed: Oct. 3, 2012. doi: 10.1177/104063871002200314.

LITTMAN, M.P. Hypertension. In: ETTINGER S.J.; FELDMAN E.C. Textbook of Veterinary Internal Medicine. 5.ed. Philadelphia : WB Saunders, 2000. p. 179-182.

LUIS FUENTES, V. et al. ACVIM consensus statement guidelines for the classification, diagnosis, and management of cardiomyopathies in cats. Journal of Veterinary Internal Medicine, 2020. Available from: <https://www.ncbi.nlm.nih. gov/pubmed/32243654>. Accessed: May, 8, 2020. doi: 10.1111/ jvim. 15745 .

LYONS, L.A. et al. Feline polycystic kidney disease mutation identified in PKD1. Journal of the American Society of Nephrology, v.15, n.10, p.2548-2555, 2004. Available from: $<$ http://www.ncbi.nlm.nih.gov/pubmed/15466259>. Accessed: Oct. 3, 2012. doi: 10.1097/01.ASN.0000141776.38527.BB.

MARTINEZ-VEA, A. et al. Left ventricular hypertrophy in hypertensive patients with autosomal dominant polycystic kidney disease: Influence of blood pressure and humoral and neurohormonal factors. American Journal of Nephrology, v.20, n.3, p.193-200, 2000. Available from: <https://www.ncbi. nlm.nih.gov/pubmed/10878400>. Accessed: Nov. 13, 2012. doi: $10.1159 / 000013583$

MARTINEZ-VEA, A. et al. Exercise blood pressure, cardiac structure, and diastolic function in young normotensive patients with polycystic kidney disease: A prehypertensive state. American Journal of Kidney Diseases, v.44, n.2, p.216-223, 2004. Available from: $\quad<$ https://www.ncbi.nlm.nih.gov/pubmed/15264179>. Accessed: May. 13, 2015. doi: 10.1053/j.ajkd.2004.04.026.

MEURS, K.M. et al. A cardiac myosin binding protein $\mathrm{C}$ mutation in the Maine Coon cat with familial hypertrophic cardiomyopathya. Human Molecular Genetics, v.14, n.23, p.35873593, 2005. Available from: <https://www.ncbi.nlm.nih.gov/ pubmed/16236761>. Accessed: May, 10, 2019. doi: 10.1093/hmg/ ddi386.

MEURS, K.M. et al. A substitution mutation in the myosin binding protein $\mathrm{C}$ gene in ragdoll hypertrophic cardiomyopathy. Genomics, v.90, n.2, p.261-264, 2007. Available from: <https:// www.ncbi.nlm.nih.gov/pubmed/17521870>. Accessed: May, 10, 2019. doi: 10.1016/j.ygeno.2007.04.007

PAAVOLA, J. et al. Polycystin-2 mutations lead to impaired calcium cycling in the heart and predispose to dilated cardiomyopathy. Journal of Molecular and Cellular Cardiology, v.58, p.199-208, 2013. Available from: <https://www.ncbi.nlm.nih. gov/pubmed/23376035>. Accessed: Dec. 21, 2019. doi: 10.1016/j. yjmcc.2013.01.015.

PEDERSEN, K.M. et al. Increased mean arterial pressure and aldosterone-to-renin ratio in Persian cats with polycystic kidney disease. Journal of Veterinary Internal Medicine, v.17, n.1, p.21-27, 2013. Available from: <http://www.ncbi.nlm.nih.gov/ pubmed/12564723>. Accessed: Feb. 3, 2014. PubMed PMID: 12564723 .

PEDROZO, Z. et al. Polycystin-1 is a cardiomyocyte mechanosensor that governs 1-type $\mathrm{Ca} 2+$ channel protein stability. Circulation, n.131, v.24, p.2131-2142, 2015. Available from: $<$ https:/www.ncbi.nlm.nih.gov/pubmed/25888683>. Accessed: Dec. 21 , 2019. doi: 10.1161/CIRCULATIONAHA.114.013537.

PHILLIPS, J.K. et al. Temporal relationship between renal cyst development, hypertension and cardiac hypertrophy in a new rat model of autosomal recessive polycystic kidney disease.. Kidney and Blood Pressure Research, v.30, n.3, p.129-144, 2007. Available from: $<$ https://www.ncbi.nlm.nih.gov/pubmed/17446713>. Accessed: Dec. 5, 2015. doi: 10.1159/000101828.

RUSH, J.E. et al. Population and survival characteristics of cats with hypertrophic cardiomyopathy: 260 cases (1990-1999). Journal of the American Veterinary Medical Association, v.220, n.2, p.202-207, 2002. Available from: <https://www.ncbi. nlm.nih.gov/pubmed/12126131>. Accessed: Nov. 3, 2014. doi: 10.2460/javma.2002.220.202.

SAGGAR-MALIK, A.K. et al. Left ventricular mass in normotensive subjects with autosomal dominant polycystic kidney disease. British Medical Journal, v.309, n.6969, p.16171618, 1994. Available from: <https://www.ncbi.nlm.nih.gov/ pubmed/7819937>. Accessed: Aug. 14, 2014. doi: 10.1136/ bmj.309.6969.1617.

SNYDER, P.S. et al. Effect of amlodipine on echocardiographic variables in cats with systemic hypertension. Journal of Veterinary Internal Medicine, v.15, n.1, p.52-56, 2001. Available from: $<$ https:// www.ncbi.nlm.nih.gov/pubmed/11215913>. Accessed: Sep. 24, 2014. doi: 10.1892/0891-6640(2001)015<0052:eoaoev>2.3.co;2.

THOMAS, W.P. et al. Recommendations for standards in transthoracic two-dimensional echocardiography in the dog and cat. Echocardiography Committee of the Specialty of Cardiology, American College of Veterinary Internal Medicine. Journal of Veterinary Internal Medicine, v.7, n.4, p.247252, 1993. Available from: <https://www.ncbi.nlm.nih.gov/ pubmed/8246215>. Accessed: Nov. 25, 2015. doi: 10.1111/j.19391676.1993.tb01015.x 
TILLEY,L.P. Essentials of canine and feline electrocardiography: interpretation and treatment. 3.ed. Philadelphia : Lea \& Febiger, 1992. 470p.

TIMIO, M. et al. The spectrum of cardiovascular abnormalities in autosomal dominant polycystic kidney disease: a 10-year followup in a five-generation kindred. Clinical Nephrology, v.37, n.5, p.245-251, 1992. Available from: <http://www.ncbi.nlm.nih.gov/ pubmed/1606775>. Accessed: Out. 18, 2014. PubMed PMID: 1606775 .

VALERO, F.A. et al. Ambulatory blood pressure and left ventricular mass in normotensive patients with autosomal dominant polycystic kidney disease. Journal of the American Society of Nephrology, v.10, n.5, p.1020-1026, 1999. Available from: <http://www.ncbi. nlm.nih.gov/pubmed/10232688>. Accessed: Nov. 30, 2014. PubMed PMID: 10232688.

WANG, D. et al. Endothelium-dependent relaxation of small resistance vessels is impaired in patients with autosomal dominant polycystic kidney disease. Journal of the American Society of Nephrology, v.11, n.8, p.1371-1376, 2000. Available from: <http:/www.ncbi.nlm.nih.gov/ pubmed/10906150>. Accessed: Dec. 13, 2015. PubMed PMID: 10906150.

WESS, G. et al. Association of A31P and A74T polymorphisms in the myosin binding protein $\mathrm{C} 3$ gene and hypertrophic cardiomyopathy in Maine Coon and other breed cats. Journal of Veterinary Internal Medicine, v.24, n.3, p.527-532, 2010 Available from: <http://www.ncbi.nlm.nih.gov/pubmed/ 20412438>. Accessed: Feb. 13, 2017. PubMed PMID: 20412438. 